\title{
РАЗЛПКАУ ВЕДРИНИ
}

\section{TOMAС МАН СМРТ У ВЕНЕЦИЈИ И ИВО АНДРИЋ БАЈРОН У СИНТРИ}

Сажетак: У раду се компаративном методом проучавају две приповетке: Смрт у Венеиији Томаса Мана и Бајрон у Синтри Иве Андрића. Указивањем на сличне мотиве и обраде истих, повезују се поетике двају писаиа. Компарачија се остварује на четири различита нивоа: обрада градова у овим приповеткама, уметници јунаци приповедака, форма лепоте и љубави за којом трагају, и различито деловање лепоте и ьубави на юих. Поступии и делована главних јунака отварају општеважећа морална питања. Тема ьубави у исто време повезује и раздваја ове приповетке. Посебна пажњ асмерена је на дефинисање разлика у ведрини коју носе ове приповетке.

Кључне речи: Томас Ман, Иво Андрић, Венеиија, Синтра, лепота, лепа бића, деструктивност

\section{Увод у проблем}

Приповетка Смрт у Венецији, Томаса Мана (Thomas Mann), објављена је 1912. године. Нешто касније, 1935, Иво Андрић је објавио приповетку Бајрон у Синтри. Паралеле између дела Томаса Мана и Иве Адрића су већ одавно присутне у критици. Иво Тартаља у Приповедачевој естетици образлаже „Андрићеву сродност по избору”" са Томасом Маном. Петар Џаџић у студији Митско у Андрићевом делу уочава две додирне тачке између Мана и Андрића: „развојни пут уметника” и „понирање у легенде човечанства", и Радован Вучковић у Великој синтези о Иви Андрићу предочава

1 Тартаља, И. (1979) Приповедачева естетика, Београд: Нолит, стр. 86.

2 Џаџић, П. (1992) Митско у делу Иве Андрића (Храстова греда у каменој капији), Београд: Научна књига, стр. 24. 


\section{ЈЕЛЕНА ЂОРЂЕВИЋ}

подударности Проклете авлије и Мановог романа Јосиф $u$ његова браћа.

Указивања критике на блискост двају писаца и њихових јунака су јасне, али разлике између њих су још упечатљивије. Две етапе писања, два процеса, две приповетке Cмрт у Beнецији и Бајрон у Синтри оштро се разликују по односу писаца, уделу свести али прожима их једно стремљење, сродност циља. Јунаци ових приповедака, могло би се тврдити, повезани су истом љубавном нити.

Два иста пута, два трагања за лепотом, Маново и Андрићево, само су наизглед исти, али се суштински разликују. Немогуће је говорити о лепоти, а прећутати љубав коју та лепота изазива у човеку. Лепота отелотворена у два људска бића различитих полова, разликује се у осећањима. Оба су са назнаком нечег демонског, оба су као сновиђења, али је Андрићево „мало створење” етеричније од Мановог, чистије и свеобухватније. Оно изазива душевна страдања, патњу и бол, али та патња више личи на катарзу коју преживљава књижевни јунак, да би се на крају показао светлијим и бољим.

Жудња као неостварен сан и неутешна жеђ лебди над Ашенбахом и Бајроном, она се нуди као лепота, загонетка и тајна. Енергије Тађа и девојчице из Синтре нису подударне са духовним енергијама Ашенбаха и Бајрона, стога наступа жудња. Немогућност одјека и преливања енергије у друго биће ствара свет без узајамне привлачности и унутрашњег прожимања.

\section{Град}

Ман и Андрић, приступају различитим решењима приказа града у који смештају радњу. Своје градове - јунаке они бирају према јунацима приповедака, према њиховим тежњама и жељама. Венеција је град љубави, карневалски град, град који под маскама крије своје лепоте. У такав град, град са богатом љубавном историјом, Томас Ман је сместио Ашенбаха, његову заљубљеност и тежњу ка лепом Тађу. Синтра је градић у близини Лисабона, града фадо музике и романтике. Град у коме су наглашене патње за неоствареним љубавима, у коме се чула изоштравају и маме на љубав, адекватан је за Бајронову чежњу.

Град је одредница спољашњег простора који је отворен, приступачан свакој људској јединки, док унутрашњи простор човек ствара само за себе, као сопствено склониште. Венеција је град у северној Италији, која оличава укрштање различитих стилова: италијанског, арапског, византијског и 
ренесансног. Манова интересовања и искуства инспирисала су и створила овај град - лик. Томас Ман је боравио у Венецији 1911. године, ова посета је у многоме допринела настанку приче. ${ }^{3}$

Густав фон Ашенбах долази из Минхена, потом паробродом преко Пуле у Венецију. Његов доживљај Венеције и њене лепоте је променљив, и одговара променљивости његовог расположења. Жеља за путовањем, и Венецијом, код Ашенбаха се јавља као жеља за бегом, чежња за далеким и новим, и жудња за ослобођењем. Као логичан избор, након дужег премишљања, намеће се Венеција. Венеција гони у слободу:

„И тако ју је опет угледао, чудесну луку, онај заслепљујући склад фантастичних грађевина који је Република износила пред погледе морепловаца пуне страхопоштовања: лаку дивоту палате и моста уздисаја, стубове на обали са лавом и свецем, бок храма из бајке, гиздаво истурени, поглед на пролаз кроз капију и на џиновски сат; и гледајући промишљао је да онај који у Венецију стиже сувим, на железничкој станици, улази у палату на стражња врата, и да не треба никако другачије долазити но што он сада чини, да треба само бродом, само са високе пучине стизати у најневероватнију варош."

Амбивалентна природа Ашенбахова једнака је амбивалентној природи његовог доживљаја Венеције. Она је „мазна лепотица” и „невероватна варош”, али и место које Ашенбаху доноси унутрашњи немир. Мирис Венеције, који прати Ашенбаха, мирис је трулежи, одвратне запаре, који лежи по улицама. У тренутку кад пожели да је напусти, он ће осетити бол, дубоку душевну патњу и ношен тим осећањем вратиће се натраг. „Венеција Вагнера, највеће опасности, Венеција Ничеа, спасиоца, који ју је опевао лепше но ико, - она се ту прелива са својих 'тисјућ шарених самоћа', као сликовна позадина за јасну пластику предње фигуре. Најфантастичнији комад истока пренесен у европску класику, она је тле камо се излила страшна болест и дионизијски занос који обоје долазе са истока, из исте Индије... Па ипак, јасније но Венеција која је присутна у стварности, живи ту Хелада,

3 Катја Ман (Katia Mann), жена немачког писца, посведочила је о опчињености аутора једанаестогодишњим дечаком на путовању у Венецију у књизи Моји ненаписани мемоари. Као модел за Тађа, главног јунака приче, Ману је послужио пољски барон Владислав Moc (Wladyslaw Moes), кога је као дечака заиста срео у Венецији.

4 Ман, Т. (2001) Смрт у Венецији, у: Изабрана дела (прир. Аница Савић Ребац), Београд: Дерета, стр. 169. 


\section{ЈЕЛЕНА ЂОРЂЕВИЋ}

присутна у идеји: Хелада Платона и пластике, у мислима Ашенбаховим и у фигури лепога дечака."5

Ман и Андрић на различите начине приказују своје градове - јунаке. Венеција је променљива, нестална, Синтра је сублимирана, јер Бајронова осећања и тежње ка лепом нису несталне и промељиве. Бришући границе између спољашњег и унутрашњег света, Андрић нам ускраћује опис природних лепота Синтре, дајући предност Бајроновом унутрашњем свету. У Андрићевој причи Бајрон у Синтри, нема ниједног описа те лепоте, ниједне речи о чудесним грађевинама и маурској архитектури ${ }^{6}$.

Андрић највероватније није успео одолети чаробној Синтри, те ју је, можда, описао барем у оном делу кад Бајрон с друштвом и послугом улази у градић. Међутим, од претпостављеног описа остао је само делић:

„Пред њим су се отварале све нове терасе, све нови путеви и све шири видик: дванаест миља зелене равнице уоквирене појасом мора и бескрајем неба. Није осећао напор. Чинило му се не да се пење, него да расте. Нигде жива створа. Ни птице није било. Мислио је: најпосле, ево једна земља у којој је самоћа весела!

Хитајући тим стазама урезаним у бедеме и са сталним изгледом на далеке вртове и још даље море, сусрео је изненада једну девојчицу неодређених година."7

Синтра у Бајроновом доживљају добија одлике његовог духовног стања. Он не осећа напор док се пење на зелени вис, јер тиме духовно узраста ка лепом, ка сусрету са девојчицом која ће у њему пробудити најдубљу чежњу ка бољем и

5 Савић Ребац, А. (2001) Томас Ман и проблем уметника, предговор у: Изабрана дела, Београд: Дерета, стр. 26.

6 Постоји опис градића у путопису Португал, зелена земьа, у коме Андрић описује Синтру која је „леђима прислоњена уз мрке брегове, а лицем окренута ка равници”, описује „дворац са преосталим намештајем, мало двориште са шедрваном и клупом на којој је Камоенс читао своје стихове краљу Себастијану, а сваки прозор, свака тераса, отвара пред вама, под новим углом, јединствен видик од двадсетак километара зелене равнице порубљене неодређеном пругом мора која бљешти и изгледа, у даљини, круто и непомично као да је Де пиедра, де метал, као душа Камоенсове нимфе." Описује трг с чесмом, терасе у зеленилу, бујно и зелено дрвеће по стрмим обронцима брегова, мршаве девојчице које на тргу испод терасе продају укусне и слатке колаче, „сате који искуцавају с невидљивог торња као најлепша поподневна музика"; Андрић, И. (1964) Стазе, Лииа, Предели, Београд: Младост, стр. 140.

7 Andrić, I. (2011) Priče o moru, Beograd: Laguna, str. 69-70. 
већем свету. Бајронова самоћа у Синтри је весела, самоћа након сусрета са „лепим бићем” просветљује Бајрона, чинећи га бољим. Сублимираност приказа и језгровитост Синтре у сугласју су са духовним стањем Бајрона јер он доживљава прожимање са највишим идејама као што су љубав и лепота. Синтра је ослобођена спољашних граница, физичког описа, али јој је придодато унутрашње осећање мира које не ремете живи створови.

Ашенбах се бори са Венецијом, доживљава је и мења, прилагођава. Бајрон је кратко и једноставно у Синтри. Она се пред њим отвара, гурајући га у просторе фантазије. Јунаци приповедака Смрт у Венечији и Бајрон у Синтри руше природне границе, стварајући унутрашње светове засноване на тежњи ка лепом и љубављу. Улогу прозора, портала између два света заузимају отелотворења ових тежњи. Физички простор, град - јунак, при сусрету са лепим бићем поприма особине унуташњег света главног јунака, чиме се бришу границе између два света.

\section{Проблем уметника}

Два града, превазилазе своје физичке одреднице, сублимирајући се у истој жељи и чежњи. Трагање за лепотом повезује два уметника, али их раздваја деловање лепоте. Ашенбахова лепота је себична, заробљена у Тађу без могућности да се подели, Бајронова, оличена у младој Лисабонки, лепота је која се умногостручава. Ашенбах је поражен на животном и љубавном плану, Бајрон, међутим, одаје утисак испуњености. Лична искуства Томаса Мана и Иве Андрића о сукобу грађанина и уметника у једној особи, добила су самосталан живот у ликовима Бајрона и Густафа Ашенбаха. Екстаза уметника носи ванчовечан карактер, често њихова човечност долази из оскудице човечности, што уметника чини најпогоднијим за судар с лепим.

Густав Ашенбах је јунак Томаса Мана, замишљен као признати и поштовани уметник. Он је своју уметничку егзистенцју засновао на одлуци да пориче знање, да га одбацује уколико је оно подобно да обесхрабри, понизи вољу, осећај и страст. „Слом и трагика Густава Ашенбаха, и као уметника и као човека, јављају се на подлози његовог психолошкоморалног портрета са почетка приповетке. Тек сагледавањем распона између онога, што је, према слову приповести, био његов живот и онога што се насупрот томе, догодило у Венецији (у равни реалних збивања) и у његовом духу ( у симболичко митолошкој равни, која ону реалну 'допуњуje' и објашњава), могуће је схватити и проценити размере 


\section{ЈЕЛЕНА ЂОРЂЕВИЋ}

његове трагике." Битне црте Ашенбахове стваралачке личности су у сагласју са Ничеовим идејама, које су у великој мери одредиле Маново стваралаштво. Ман је о уметнику говорио као о човеку, борбу човека и духа пренео је на појединца који је грађанин и уметник.

Андрић је свом јунаку дао име славног писца Бајрона9. Слободарски дух и песничко дело енглеског бунтовника несумњиво су надахнули Андрића, те је у центар сукоба са лепотом поставио „синоним романтизма”10. За дела Бајрона индикативан је један посебан тип јунака, чији се велики део карактеристика може приписати самом писцу. Писца Бајрона и бајроновског јунака карактерише гајење љубави коју је срушило друштвено неодобравање, побуна, прогонство, тајна прошлост. Неко ко је бежао од незадовољавајуће стварности у животу, погодан је за сусрет с лепим у књижевном делу. „Проглашавајући живот сваког чулника за пакао, Андрић у овој причи говори о драми људске жеље уопште, како је он види, при чему оно специфично романтичарско, и бајроновско, у томе не мора, и не треба, да буде пренебрегнуто или потиснуто у тумачењу." 11

Трагање за формом универзално лепог је вечно, несумљиво је само уметнику дато да у физичком облику пронађе метафизику, стога не чуди избор главних јунака великих умова, сродних по блискости.

\section{Трагање за формом лепог, трагање за љубављу}

Сложен сплет духовних проблема, психолошког развоја и естетских значајности на сличан начин приказан је у двема приповеткама. Брисање границе између уметности и живота може учинити само појава лепоте. Смерна и изазовна, тајанствена, таква лепота је недостижна иако је на дохват руке. Ман и Андрић своје јунаке стављају пред исту фасцинацију фасцинацију лепотом.

8 Стојановић, Д. (1997) Парадоксални класик Томас Ман, Београд: Завод за уџбенике и наставна средства, стр. 33.

9 Лорд Џорџ Гордон Бајрон (George Gordon Byron) (22. јануар 1788 - 19. април 1824) био је песник, енглески романтичар; стекао је међународну књижевну славу епом Чајлд Харолд, а потом и поемом Дон Жуан. Његов живот и дело уско су повезани, допуњују се и стварају готово недељиву целину. Подаци говоре да је Бајрон боравио у Лисабону 1809, вероватно да је тада посетио и Синтру. Путописи, писца Бајрона, и његова путовања сведоче о лепоти овог града, зато не чуди спој главног јунака приче и места радње.

10 Стојановић, Д. (2003) Лепа бића Иве Андрића, Подгорица / Нови Сад: Цид / Платонеум, стр. 60.

11 Исто, стр. 60. 
Млади Ерос, отелотворење жеља Ашенбахових, помаља се пред њим „као пространи вечерњи хоризонт”. Са чуђењем ће Ашенбах приметити његову савршену лепоту, бледи и љупко озбиљни лик, који је окружен увојцима косе боје меда. Лепота дечака, опис његових чари, подсећа на најљубавнији приказ жене, на Петраркину Лауру која се из Канцонијеpa пренела у Манову Венецију. Плави увојци Тађа, који се спуштају на чело и врат, његова кожа боје слонове кости, подсећају на лепоту античких скулптура. Обавијена велом митологије и магновења, Тађова лепота је смртоносна.

Сваки нови сусрет са Тађом, Ашенбаху доноси нову фасцинацију, нову занесеност и опчињеност, али она није једнострана фасцинација лепотом, већ љубавни занос. Ашенбах ће у једном тренутку, себи признати ту недозвољену љубав:

„(...) шапутао је освећену формулу чежње, - немогућну овде, апсурдну, недостојну, покварену, смешну, а ипак свету, још и овде часну: 'Ја те волим!'”12

Поставља се питање, да ли Тађо као „лепо биће” провоцира да буде вољен. Фасцинација лепотом није једнака љубави, али оне настају из истих енергија. Тађо се Ашенбаху само смешио: блиско, умилно и отворено, осмехом без завођења, без претензија.

„Био је то осмех Нарциса који се нагиње над водено огледало, онај дубоки, очарани, привучени осмех са којим он пружа руке према одсеву рођене лепоте, - један сасвим мало грчевити осмех, грчевит без безнадности своје тежње да пољуби дражесне усне своје сенке, кокетан, радознао, и нешто мало измучен, залуђен и залуђујући."13

Митологија сунца и сунчеве светлости, јавиће се као рефлекс космогоније и поетске митологије сунца. Сунце одвраћа Ашенбахову пажњу са интелектуалних појава на чулне, толико да његова душа од радости заборавља на своје право стање.

Јер лепота, мој Фаидре, само она је у исти мах и драга и видна: она је, упамти то! Једини облик духовнога света који можемо примити чулима, поднети чулима. А шта ли би било с нама кад би нам се разум и врлина и истина чулно приказали? Не бисмо ли нестали и сагорели од љубави, као некада Семела пред Зевсом? И тако је за човека који осећа лепота пут ка духу - само пут, само средство, мали Фаидре... А

12 Ман, Т. нав. дело, стр. 209.

13 Исто, стр. 210. 
затим је изрекао најфиније лукавство, тај препредени удварач: То наиме да је онај који љуби божанскији од љубљенога, јер је у ономе бог, а у овоме није, - ту најнежнију, најподругљивију, можда, мисао која је икада замишљена, из које извире сва враголнија и сва најтананија сласт чежње. ${ }^{14}$

Лепота се неминовно доводи у везу са љубављу. Заљубљеност Ашенбахова у младог Тађа, открива се у његовој љубомори и брижности. У тренутку када најбољи Тађов друг, кога су звали „Јашу”, пољуби Тађа у образ, Ашенбах долази у искушење да му припрети прстом. Љубомора добија свој виши облик, облик брижности, када је Тађо оборен у песак, Ашенбах ће пожелети да му помогне.

Ашенбахова опијеност лепотом Тађа је еротског карактера. Његова чежња за дечаком равна је опсесији. Ашенбах прати Тађа у жељи да га додирне, да му се обрати, неуморно га посматра и тражи у туђим лицима, налик је предатору који вреба своју жртву, а опет, у тренутку кад јој се приближи он устукне.

Андрићев јунак се такође предаје фасцинацији лепотом, али она не добија призвук еротског. Андрићева, као и Манова, естетика скопчана је са демонизмом. Бајрон поседује одлику демонског - хромост. „Зло које води ка лепоти не може остати то што јесте у својој изворној непомућености“"15 Бајрон видевши у магновењу благу и насмејану младу Португалку осећа стид, као прикривени осећај кривице. „Непознато зло” је отерало Бајрона из Енглеске, „шибајући га светом”, зло истоветно чежњи Ашенбаха за путовањем, и Венецијом. Предодређени за сусрет са исконским, у овим јунацима јавља се зло, као жеља за бегом, чежња за далеким и новим, жудња за ослобођењем.

Етерична лепота у приповеци Бајрон у Синтри обавијена је велом демонског. Чињеница да се млада Португалка јавља у сумрак даје јој извесну „соларну природу” која је измењена, али и даље упућује на сјајно, лепо, свето и светло. Одевена у белу хаљину Португалка је маркирана белом бојом која симболизира чистоћу, свежину, лакоћу и доброту, али је синоним и за зиму, хладноћу и даљину. Она је симбол невиности, чистоће и поштења, али у појединим културама ова боја симболизира тугу и жаљење. Девојчице одевене у белу хаљину се у немачким легендама, појављују у подне и заслепљују својом лепотом. Сматрају их добрим духовима који лече и окрепљују, а Бајронова жена - привиђење не сличан

14 Исто, стр. 203.

15 Стојановић, Д. (2003) нав. дело, стр. 52. 
начин лечи и окрепљује. Она се јавља над двоструким понором, неочекивана као фантазма, послата од неке више и недостижне силе као што је и она сама.

„Стајала је на ивици бедема, поред једне мале камените стражарнице која је била напуштена и празна. Искрсла је ту пред њим неочекивано, као послата однекуд, од неког, са неком поруком. У чистој хаљини од бела платна, са загаситим полуафриканским лицем, малим носом широких носница, које одају непосредност, и са паметним очима пуним здравља и веселости." $" 16$

Узаврелу крв и жеђ, изазвану близином жене Бајрон је гасио „и неком ослобођеном, новом и светлом мишљу обухватао ово живо и насмејано људско створење"17

Андрићева млада Португалка није налик на саблажњиву Лолиту Набокова. Хумберт свесно признаје да је Лолити уништио детињство и прерано је гурнуо у свет одраслих, док Бајрон насупрот томе није учинио ниједан корак који би скинуо вео недодирљивости са младе Португалке. Њене суве усне маме и изазивају узбуђење налик еротском, али она делује безазлено и чедно. Андрићев сензуални приказ усана, једини је тон еротског:

„Њихала се лагано и гледала га, насмејана, право у очи, влажећи језиком увек суве усне. Ништа нема узбудљивије од усана ових португалских жена! Оне имају нешто и од вегеталног и од минералног света. Неправилне као случајно распукла смоква, оне показују од какве је вреле, тамне и слатке крви панутрица овог ситног и дозрелог тела. Тек на крајевима оне су малко моделиране као усне у жена кавкаске расе, али и ти кутовови усана губе се у неодређеној сенци, као пузући на лишћу биља."18

Жена са брега из Синтре имала је чисту беоњачу и зенице као од топаза које у Бајрону буде жудњу и жељу. Међутим, култура стида и снебивања делује неумољиво. „Жеља није снебивљива, ако је неометена, нити се руководи пре свега поштовањем. Дивљење према лепоти у коме она може учествовати као жеља, није, како је у овој причи схваћено, довољна заштита 'светињи личности' пред акцијом жеље која испуњава 'муљевите визије'"19 Његова жудња је неутољена,

16 Andrić I. (2011) нав. дело, стр. 70.

17 Исто.

18 Исто.

19 Стојановић, Д. (2003) нав. дело, стр. 56. 
жеља неиспуњена, док очи младе Португалке неуморно прате своју жртву. Две зверке се обилазе и њуше, њихов сусрет на зеленом вису у Синтри представља сусрет са лепотом која се не присваја.

Драган Стојановић наводи да је лепоти тешко у скученом свету, „лепом бићу посебно неиздржљиво”20, међутим, Бајроново „лепо биће” остаје чисто и чедно, јер лепота његовог бића није деструктивна, ни по себе, ни по самог Бајрона. Лепота која у Венецији прогони Ашенбаха, уништава саму себе па Тађо одаје утисак болешљивог дечака, али је лепота кобна и по самог Ашенбаха.

\section{Лице и наличје лепоте - лице и наличје ьубави}

Лепота и љубав су често угрожене и угрожавајуће, могућностима да занесу, оне се шире на друга бића, деловања лепоте и љубави у том слислу су различита, у додиру са лепим открива се човекова природа, открива се лице и наличје љубави. Ашенбах и Бајрон су смртници који се срећу са исконским. Њихове природе се разликују, те и лепота различито делује на њих. „Лепота изазива поремећаје сваке врсте, али немогуће је проћи поред ње, као да није ни била виђена, као што није могуће стајати пред њом 'па гледати'."21 Разум се повлачи пред призором лепоте, а трагика уметника постаје израженија, видљивија.

На Мановог јунака лепота делује деструктивно, скоро гротескно. Прилазећи Венецији, Ашенбах се згражава над призором старог кицоша који наклапа о својој драгани, над његовим очајним покушајем да изгледа млађе, да буде млађи. Под утицајем сусрета са Тађом, Ашенбаха је гонило да се телесно освежи и обнови. Жеља за поседовањем лепоте (своје и туђе) Ашенбаха чини смешним, претварајући га у кловна неког урнебесног циркуса. Седећи заваљен у столицу, под притиском лепоте, чинио је оно што га је згражавало, покушавао је да буде млађи. Фарбајући косу, чинећи обрве сразмернијим, подцртавајући капак, стваљајући на усне кармин, Ашенбах се претвара у слику која је у њему пробудила грозу.

„Козметичар се најзад задовољи, и по обичају таквих људи захваљивао је са пузавичком учтивошћу оном кога је таман услужио. 'Незнатна помоћ', говорио je, додајући још при крају неку ситницу Ашенбаховој спољашњости, 'господин се сада може мирно

20 Исто, стр. 30.

21 Стојановић, Д. (2003), нав. дело, стр. 342. 
заљубити'. Опчињени оде, срећан као у сну, збуњен и страшљив. Кравата му је била црвена, сламни шешир са широким ободом био је омотан траком у више боја." 22

Ашенбахово „улепшавање” само је почетно делање у низу. Ашенбах који се посветио богу логике Аполону и који је одбацио моћ Диониса, сада је изложен његовом гневу. Изгледа да је Дионис пратио Ашенбаха у Венецију, са намером да га уништи. Млади Ерос је Ашенбахова персонификација љубавне страсти и стваралаштва. Платон Ероса у Гозби означава као демона. Демонска природа Тађа сакривена је у жудњи коју он изазива у Ашенбаху. Тађо Ашенбаху доноси безнађе и смрт, лишавајући га и општеважећих моралних начела. Занесен сопственом чежњом, жељом, Ашенбах ће ризиковати живот вољеног. Он сазнаје да у Венецији влада куга, свестан чињенице да она може угрозити живот осетљивог Тађа, неколико пута ће пожелети да упозори пољску породицу на долазећу болест. Страх да ће изгубити прилику „лепог” му не дозвољава да то учини. Пред љубављу Ашенбах несвесно постаје деструктиван, губећи из вида морална начела.

Као крајњи резултат додира са деструктивном силом лепоте, уследиће смрт. Ерос, Танатос и Фобос се сублимирају у Ашенбаху. Страх да може остати без „лепог бића” страшнији је од смрти саме. Танатос се Ашенбаху пришуњао, док он очима прати младог Ероса. Гледајући Тађа као да га види први пут, утонуо је у дубок сан, а већ истог дана свет је примио вест о његовој смрти. За разлику од Манове приповетке, која фасцинацију лепотом повезује са смрћу, код Андрића лепота не доноси уништење, ни Бајрона а ни девојчице.

Млада Португалка за Бајрона није само оличење лепоте, она је надасве људско биће, које има своју крв, своје срце, очи, родитеље. Он неће учинити ништа што би пољуљало њено детињство или је пореметило на било који начин, те она не подлеже уништењу. Оно се не приближава ни младој Португалки довољно да јој измени детињство и тиме упрља њену чистоту, али ни Бајрону, јер га сусрет са лепотом чини питомијим и бољим. Оно што човека учини бољим не може имати примесе деструктивности и аутодеструктивности, а таква љубав је најлепши хвалоспев љубави.

Бајрон Мало створење чува у себи, као кратак дах иза склопљених усана не желећи да га оно напусти. Сусрет са

22 Ман, Т. нав. дело, стр. 236. 
лепотом, са Малим створењем послатим однекуд, Бајрона оплемењује, чини га бољим. У говору ју је проналазио у речима, у потпису је додао малу цртицу која је њен траг. Лепота је остала у њему заробљена, умножена. „Блискост без близине, сједињеност без додира, миље у коме је више пажње и поштовања него радости жеље, то је Бајрону донео сусрет у Синтри."23

Лепота коју је донела млада Лисабонка је исцелитељска, насупрот деструктивној лепоти Мановог Тађа. То је лепота која лечи, оплемењује, шири човекове видике изван постојећих хоризоната.

Додир са њом, у сећању, лечио га је и чувао од свих сусрета, од жена, и од живота самог. А у нарочито сетним тренуцима, за сутона на морској пучини, дешавало се чудо, истинско, необјашњиво и неописиво: зелени брег у Синтри претварао се у небеску светлост без краја, његово хромо трчање у безгласни дуги лет, а сва чулна грозница тога сусрета у чист подвиг духа без болне свести и границе. ${ }^{24}$

Љубав добија нову чулност, нови облик који Бајрону изнова искрсава пред очима, те Бајрон остаје чист, оплемењен. „Андрић није представио биће испуњено љубављу као екстатичној радости живота, али трагичним исходом љубавног заноса није потирао унутрашњу срећу која човека без обзира на животни удес чини бољим и, у једном посебном смислу речи лепшим." 25 Девојка из Синтре материјализује се у лимуну, соли, уљу и малвасији добијајући нови израз:

„Он је могао за ручком од двадесет особа да дозове зелену Синтру и њено мало створење, играјући се неприметно са два зрна соли између палца и кажипрста." 26

Бајронова игра са два зрна соли је налик на магијски моменат, на бајање и чаролију, која ће у сећању оживети Мало створење, која ће му удахнути нови живот. Израз Бајронове љубави превазилази границе физичког, не изврће се и не изобличава у њему, већ добија једну нову и племенитију форму. „Она није у свему што га окружује, али озарује блаженим миром тренутак у којем, усред светске вреве, он успева да је 'дозове' играјући се с два зрна соли међу прстима. Чистота

23 Стојановић, Д. (2003) нав. дело, стр. 59.

24 Andrić, I. (2011) нав. дело, стр. 74.

25 Jerkov, A. (1997) Ljubav u pričama Ive Andrića, pogovor, u: Ivo Andrić, Ljubav u kasabi $i$ druge tragične ljubavi, Ljubljana: Jugoslovenska knjiga, str. 228 .

26 Andrić, I. (2011) нав. дело, стр. 73. 
соли прелази на њу, и значи њу, као што се њена лепота згрушњава и присутна је у зрну соли. Одсутна, она даје више, и тек тако оно најбоље, што узноси, крепи и блажи уздрхталу и немирну душу."27

Онда када Мало створење почиње да ишчезава из Бајроновог сећања, он ће се осетити осиротелим, очајним, немоћним. Када лепота у свом узвишеном облику напусти Бајрона подиже се зла матица. Она постаје тежа, већа и болнија с одласком ,лепог бића”, ипак, лепота је била довољно дуго у њему да га учини бољим.

Човекова природа тежи сједињењу са лепотом, са бићем које сматра лепим, међутим, уколико до сједињења не дође, човек посеже за рушилачким силама. Деструктивност се испољава према лепоти самој, ако је пак, немогуће уништити лепоту, човек уништава себе. Ман је у својој приповеци осликао тамну страну човека, која у размимоилажењу са лепим, нема други избор, осим смрти, деструктивности. Андрић је у том смислу већи и благороднији. Лепота у његовој визури није подложна уништењу, већ је лепота која оплемењује, топла и једноставна. Сублимираност, као главна особина Андрићрве приповетке је ,процес у којем долази до несексуалне инвестиције сексуалне енергије."28 Бајронова жеља према младој Португалки, која се зачела у Синтри, се преображава у енергију која Бајрона чини бољим човеком. Сусрет са малим створењем је Бајронова катраза, а сећање на њу амајлија која ће га у будућности штитити и скривати од зла.

\section{Закьучак}

Судар двају ликова са недостижном лепотом је, сваки на свој начин, кобан. Искакање из равнотеже је неминовно, а враћање на почетну тачку немогуће, као и остварење љубави на коју наводе „лепа бића”. Уметничка и животна дилема варирана у ликовима ових приповедака, решава се на два дијаметрално супротна начина.

Ашенбахова љубав доноси смрт, чинећи га уклетником, сатрвеног од страсти и неостварених чежњи. Бајронова љубав превазилази оквире заноса, она је без примеса чулности, она човека чини бољим, без претензија да траје вечно, траје довољно дуго да и оног, који за лепотом трага, учини лепим. „Андрић је писац типа Томаса Мана, са многоструким

27 Стојановић, Д. (2003) нав. дело, стр. 58.

28 Bužinjska, A. i Markovski, M. P. (2009) Književne teorije XX veka, Beograd: Službeni glasnik, str. 52 . 


\section{ЈЕЛЕНА ЂОРЪЕВИЋ}

даровима, са могућностима да се испољава на различите и често противуречне начине, који нам се, у целини, представи у виду једног изукрштаног сложеног и величанственог мозаика." 29

Најснажнија црта Андрићеве приповетке је сажетост, сажетост у опису, сажетост саме лепоте, док се Ман, хитајући ка приказу променљивости, расплињава. Сажетост је врлина одабраних, скривена црта Андрићевих виђења је и „узвишеност" ${ }^{\prime \prime}$, наводи Александар Јерков, несумњиво да су оне, оно најбоље у човековом бићу, у Андрићевом уметничком бићу.

Томас Ман и Иво Андрић поседују блиска схватања, Андрић се до извесне мере могао ослањати на Манову поетику, али да је његова поетика, крај свега тога - поетика писца ван времена и стварања.

\section{ЛИТЕРАТУРА:}

Андрић, И. (1964) Стазе, Лииа, Предели, Београд: Младост.

Тартаља, И. (1979) Приповедачева естетика, Београд: Нолит.

Џаџић, П. (1992) Митско у делу Иве Андрића (Храстова греда у каменој капији), Београд: Научна књига.

Jerkov, A. (1997) Ljubav u pričama Ive Andrića, pogovor u: Ivo Andrić, Ljubav u kasabi i druge tragične ljubavi, Ljubljana:

Jugoslovenska knjiga.

Стојановић, Д. (1997) Парадоксални класик Томас Ман, Београд: Завод за уџбенике и наставна средства.

Ман, Т. (2001) Смрт у Венецији, у: Изабрана дела (прир. Аница Савић Ребац), Београд: Дерета.

Стојановић, Д. (2003) Лепа бића Иве Андрића, Подгорица / Нови Сад: Цид / Платонеум.

Савић Ребац, А. (2001) Томас Ман и проблем уметника, предговор у: Изабрана дела, Београд: Дерета.

Ivanović, R. V. (2007) Miteme i poeteme Tomasa Mana, Novi Sad: Zmaj d.o.o.

Bužinjska, A. i Markovski, M. P. (2009) Književne teorije XX veka, Beograd: Službeni glasnik.

Вучковић, Р. (2006) Андрић - паралеле и рецепиија, Београд: Свет књиге.

Вучковић, Р. (2011) Велика синтеза о Иви Андрићу, Београд /

Ниш: Филозофски факултет / Алтера.

Andrić, I. (2011) Priče o moru, Beograd: Laguna.

29 Вучковић, Р. (2011) Велика синтеза о Иви Андрићу, Београд / Ниш: Филозофски факултет / Алтера, стр. 499.

30 Jerkov, А. (1997) нав. дело, стр. 228. 


\title{
ЈЕЛЕНА ЂОРЂЕВИЋ
}

Jelena Đorđević

Center for Study in Cultural Development, Belgrade

\section{DIFFERENCE IN SERENITY}

TOMAS MANN'S DEATH IN VENICE AND IVO ANDRIĆ'S BYRON IN SINTRA

\begin{abstract}
Two stories have been studied using a comparative method: Death in Venice by Thomas Mann and Byron in Sintra by Ivo Andrić. Connection in the poetics of these two authors is found by pointing out similar motifs and processing them. Comparison is achieved at four different levels: the treatment of cities in these stories; the treatment of artists as heroes of narratives; the form of beauty and love which they seek; and the different action of beauty and love for them. The actions of the protagonists provoke general moral issues. At the same time, the theme of love connects and separates these stories. Special attention is devoted to defining differences in the serenity of the narratives.
\end{abstract}

Key words: Tomas Mann, Ivo Andrić, Venice, Sintra, Ashenbah, Byron, beauty, beautiful beings, destructiveness, autodestructivity 